\title{
Enterprise architecture design using TOGAF at foundation of triputra persada horizon education
}

\author{
Arif Budimansyah Purba ${ }^{\text {a, 1, * }}$; Ahmad Mubarok ${ }^{\text {a, }}$; Jajang Mulyana ${ }^{\text {a, } 3}$ \\ ${ }^{a}$ STMIK Horizon, Jl, Pangkal Perjuangan Karawang 41316, Indonesia \\ ${ }^{1}$ arif.purba.krw@horizon.ac.id; ${ }^{2}$ ahmadmubarok941@gmail.com; ${ }^{3}$ ja2ngm@gmail.com \\ * Corresponding author
}

Article history: Received April 27, 2021; Revised July 06, 2021; Accepted July 27, 2021; Available online August 07, 2021

\begin{abstract}
The use of information technology in the field of education is currently a top priority for managing academic and supporting activities. Tri Putra Persada Horizon Education Foundation which manages two high schools, namely the College of Health Sciences and the College of Information and Computer Management should face a challenge to align business strategy with information technology, and how to integrate all the parts involved in the business and represent it in an information system. To find out the business strategy and governance of information technology used at the Tri Putra Persada Horizon Education Foundation, an Enterprises Architecture Framework is needed, one of which is TOGAF ADM. The Enterprises Architecture design contained in TOGAF ADM includes a vision architecture that defines the vision of the company or agency, a mapped business architecture in the form of value chain analysis, an information system architecture in which there is a data architecture and application architecture and the last is technology architecture. This research produced an enterprise architecture design blueprint consisting of artifacts, in the form of catalogues, matrices, and diagrams based on the phases of TOGAF ADM. The result of the Enterprise Architecture design was an integrated information system recommendation and the technology architecture. The design is expected to be a reference in improving the quality of business and is expected to make it easier to achieve the business goals of the Tri Putra Persada Horizon Education Foundation.
\end{abstract}

Keywords: Information Technology; Enterprise Architecture; TOGAF ADM

\section{Introduction}

Tri Putra Persada Horizon Education Foundation is a foundation that manages two universities, namely the College of Health Sciences (STIKes) and the College of Information and Computer Management (STMIK) Kharisma Karawang. While STIKes have a basic in the field of Health, STMIK has a basic in Information Technology. The policy taken by the Tri Putra Persada Horizon Education Foundation is to integrate business processes in the two high schools under its auspices. The purpose of the policy is to help implement the vision, mission and needs of STIKes and STMIK, one of which is improving public services. Good information technology governance is a top priority in supporting the implementation of public services [1]. The importance of digital information, such as the relationship between organizations and the public, cannot be separated from the demands in providing maximum service [7]. An information system that can integrate administrative data in all parts of the higher education is needed to represent the business processes of the two higher education institutions in the Tri Putra Persada Horizon Education Foundation. Information system is a combination of work procedures, information, people and information technology that is organized to achieve goals in an organization [2]. To integrate information technology between two higher educations, an enterprise architecture is needed that can be a reference in its implementation.

Enterprise architecture is generally defined as models, documentation, and reusable items such as components, frameworks, objects and so on, which reflect an architecture as a whole [4]. Frameworks in enterprise architecture can be used to manage complex information systems and to align business processes and invested information technology [5]. In terms of enterprise architecture modelling, there are several methodologies that can be used, one of which is the TOGAF Framework. TOGAF or The Open Group Architecture Framework is an enterprise architecture framework that provides a comprehensive approach to the design, planning, implementation, and governance of information architecture [3]. The TOGAF chosen is TOGAF ADM, because TOGAF ADM is a method that can be adapted to all changes and needs during planning. This method can also be used as a guide or tool for planning, designing, developing and implementing information systems architecture for organizations [6].

In previous study using Enterprise Architecture Design Using TOGAF at ABC University conducted by Lestari Retnawati [8], focused on designing blue prints to get an overview of ICT strategies and developments in the world 
of education. Another research is the Application of The Open Group Architectural Framework (TOGAF) Model for Enterprise Architecture Design at STMIK Widya Pratama Pekalongan conducted by Rusli et al. [9], with the aim of realizing a good governance university. And research on Application Architecture Planning at the University of Lampung Using the Zachman Framework conducted by Novianti et al. [10], aimed to find the fact that changes in application requirements were the most dominant thing to be immediately repaired in each work unit. Based on the problem formulation, the purpose of the research is to produce an Enterprise Architecture design by determining a business framework using the TOGAF ADM method and to produce an information system architecture design consisting of data architecture, application architecture, information architecture and technology architecture. This enterprise architecture design was later used as a reference in the development of an integrated information system between STMIK and STIKes Kharisma Karawang.

\section{Method}

\section{A. Architecture}

Architecture is a structured working relationship of a system consisting of hardware, software and network [11]. Architecture is also known as the basis of organizational systems that connect components in the system environment and have design and evaluation rules. The architecture in the discussion of enterprise-scale information systems is defined as the structure of components, the interrelationships, and the principles and guidelines for their design and evolution over time [12]. This understanding means that architecture is basically a picture of a company/institution/institutional structure consisting of various supporting components and the relationships between these components.

\section{B. Enterprise Architecture}

Enterprise Architecture is a framework or blueprint that serves as an organizational reference for achieving current and future business goals. Ways to achieve these business goals are by examining the keys to business success, information, application and technology governance and their impact on business functions. Each of these strategies is a separate architectural discipline and the function of Enterprise Architecture is the glue that integrates each discipline within a coherent framework as shown in Figure 1.

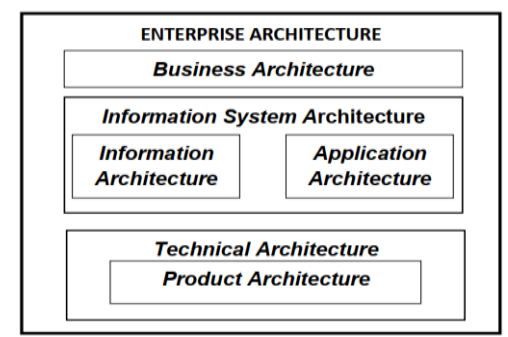

Figure 1. Relationships between Architectures in EA [13]

\section{TOGAF ADM}

TOGAF ADM, as shown in Figure 2, is a suitable and credible method for developing enterprise IT architecture and business requirements. TOGAF ADM has the necessary stages in building an enterprise architecture [14].

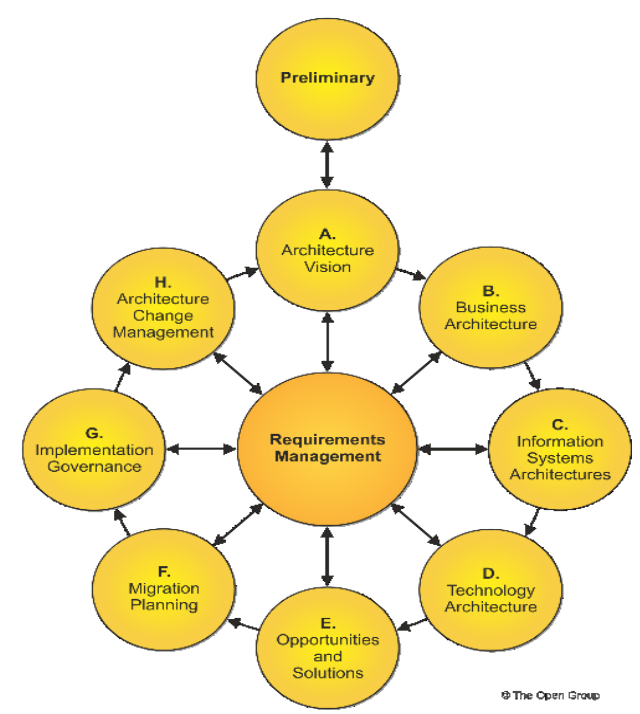

Figure 2. TOGAF ADM Framework [14] 
1. Preliminary Phase: is the stage used to determine the appropriate framework and scope of the organizational architecture.

2. 2. Architecture Vision: is the initial stage of the process of the importance of organizational architecture to achieve business goals formulated within the scope of the architecture to be developed.

3. 3. Business Architecture: this stage is used to enlarge the target and description of the current business architecture and will then be developed based on the findings of the analysis of current conditions.

4. 4. Information System Architecture: this stage prioritizes the development of the information system architecture.

5. 5. Technology Architecture: the stages are used to form the expected technological architectural design by taking into account all the procedures in selecting the required technology.

\section{Research Methods}

The steps taken in this research were:

1. Literature study

Literature study aimed to see an overview of choosing the right framework architecture to be applied in the organization.

2. 2. Assessment

The assessment consisted of two events, namely observation and interview. The observation aimed to see the first-hand conditions in the field on how the organizational architecture was applied. Interviews were conducted to obtain information from stakeholders and parts involved in the business process.

3. 3. TOGAF ADM Modeling

We Modelled the findings into TOGAF ADM based on predetermined stages.

\section{Results and Discussion}

In conducting the business processes, Triputra Persada Horizon Education Foundation has implemented information technology as a commitment to become a quality university as stated in the explanation of VISION and MISSION. To maximize the implementation of the VISION and MISSION, it requires a well-developed enterprise architecture planning in accordance with the business strategy and development of educational institutions. TOGAF $\mathrm{ADM}$ was used as a method for modeling the existing architecture in the business process environment of the Triputra Persada Horizon Education Foundation. The stages in TOGAF ADM included:

\section{A. Preliminary: Framework and Principles}

This stage explained the need for defining the vision, mission, and goals to be achieved by the Triputra Persada Horizon Education Foundation which is divided into two parts, namely STMIK and STIKes Kharisma Karawang.

STMIK Kharisma Karawang Vision and Mission:

1. The vision of STMIK Kharisma Karawang is to become a professional high school in the field of open sourcebased information technology and multimedia by 2020 .

2. To realize its vision, STIMIK Kharisma Karawang implements the mission, namely:

a. Implementing the Tri Dharma of Higher Education to support Information Technology in order to achieve higher academic degrees.

b. Creating a conducive academic atmosphere for the efficient and effective implementation of teaching and learning processes and research so as to produce graduates who excel in information technology.

c. Increase cooperation with government and private agencies or other universities to increase the competitiveness of students and alumni.

Vision and Mission of STIKes Kharisma Karawang:

1. The realization of superior and independent educational institutions in producing professionals in the health sector with the advantages of Occupational Safety and Health (K3) and Emergency that can compete in the global era in 2024.

2. 2. To realize its vision, STIKes Kharisma Karawang implements the mission, namely:

a. The implementation of quality, creative, and innovative education with the advantages of Occupational Safety and Health (K3) and Emergency.

b. Organizing research activities and scientific works in the health sector with the advantages of Occupational Safety and Health (K3) and Emergency.

c. The implementation of community service with the excellence of Occupational Safety and Health (K3) and Emergency.

d. d. The implementation of strategic, synergistic and sustainable cooperation in the scope of education, research and community service. 


\section{B. Architecture Vision}

This stage defines the vision of each architecture based on TOGAF ADM as follows:

1. Business Architecture

Defining all business activities within the scope of the Enterprise Architecure mapped into a value chain diagram.

2. 2. Information Systems Architecture

Defining data and application architectures that can support the business processes that have been defined in the business architecture.

3. 3. Technology Architecture

Defining the technology used to support business process activities and the information system used.

\section{Business Architecture}

The scope of Enterprise Architecture was defined at this stage which was mapped into the value chain diagram. The various activities carried out at the Triputra Persada Horizon Education Foundation could be identified into two group categories, namely main activities and supporting activities.

\section{Information System Architecture}

Information system architecture has two parts, namely data architecture and application architecture.

Definitions and identification were needed to know the data and application architectures that support the business architecture.

1. Data Architecture

The data architecture aimed to define the current data. The data architecture was created by referring to the results of the analysis on each business process of the academic community which was described in the value chain diagram in Figure 3. The function of the value-added chain was to describe how to see the business as a chain of activities which converted inputs into outputs so that they have value for the company [15]. From these findings, a relationship between entities and business functions was described at the Triputra Persada Horizon Education Foundation.

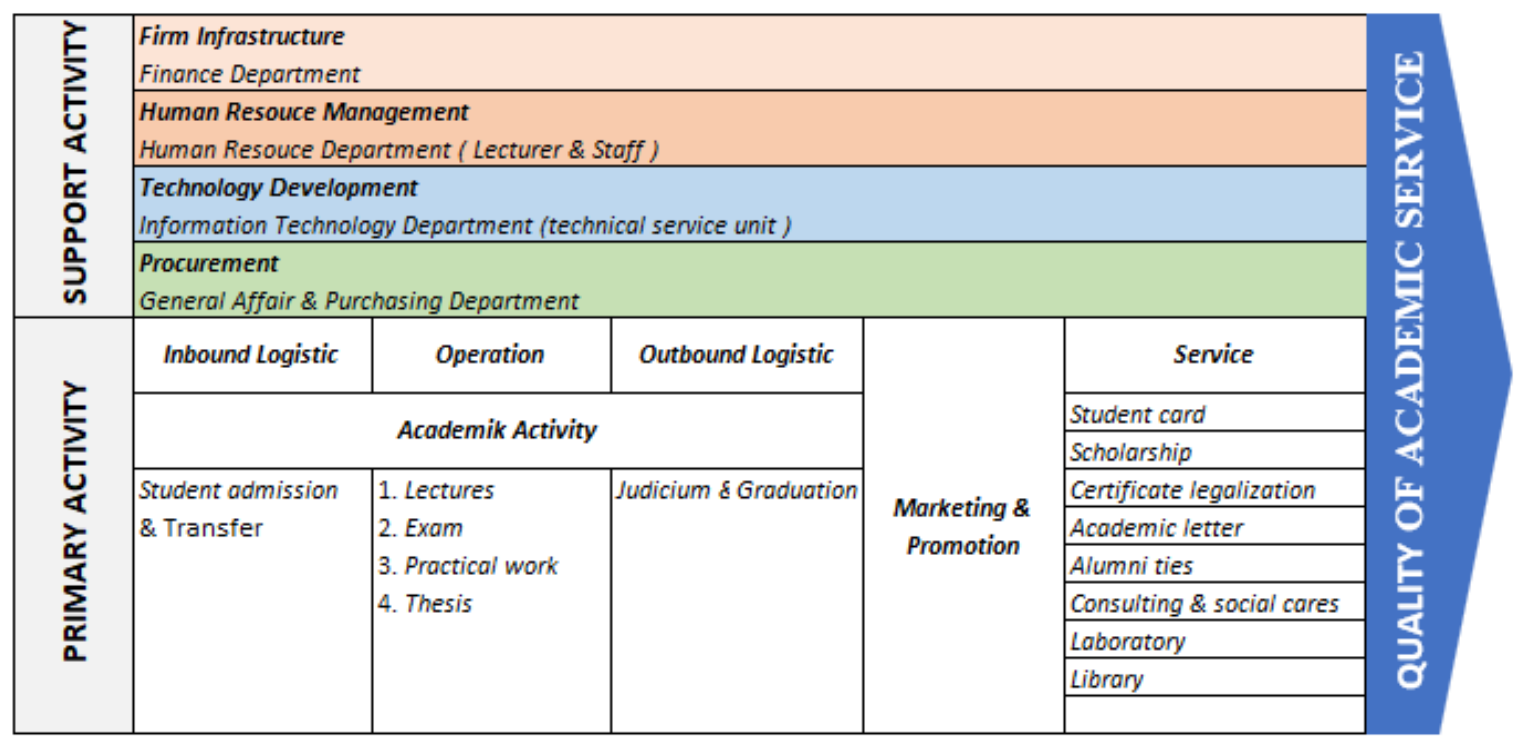

Figure 3. Value Chain Diagram of Triputra Persada Horizon Education Foundation 


\begin{tabular}{|c|c|c|c|c|c|c|c|c|c|c|c|c|c|c|c|c|c|c|c|c|c|c|}
\hline \multicolumn{23}{|c|}{ ENTITAS DATA } \\
\hline & 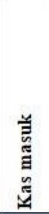 & 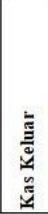 & 产 & 离 & ש్ & 言 & 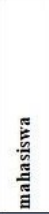 & 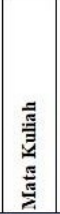 & 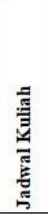 & 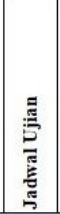 & $\begin{array}{l}\text { 胥 } \\
\text { 音 } \\
\text { E }\end{array}$ & 㑹 & $\tilde{g}$ & 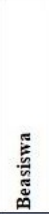 & 竎 & 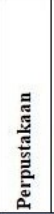 & 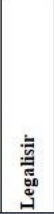 & 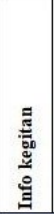 & $\frac{\vec{E}}{5}$ & 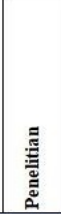 & 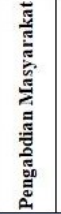 & 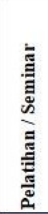 \\
\hline \multicolumn{23}{|c|}{\begin{tabular}{|l|l|}
$\begin{array}{l}\text { Fungsi layanan bisnis } \\
\text { pada akvitas pendukung }\end{array}$ & \\
\end{tabular}} \\
\hline \multicolumn{23}{|l|}{ Pengelolaan Keuangan } \\
\hline \multicolumn{23}{|l|}{ Pengelolaan Pegawai } \\
\hline \multicolumn{23}{|l|}{ Pengelolaan teknologi } \\
\hline \multicolumn{23}{|l|}{ Pengelolaan pengadaan } \\
\hline \multicolumn{23}{|l|}{$\begin{array}{l}\text { Fungsi layanan bisnis } \\
\text { pada akvitas utama }\end{array}$} \\
\hline \multicolumn{23}{|l|}{$\begin{array}{l}\text { Pengelolaan administrasi } \\
\text { Mahasiswa } \\
\end{array}$} \\
\hline $\begin{array}{l}\text { Pengelolaan kegiatan } \\
\text { perkuliahan }\end{array}$ & & & & & & & & & & & & & & & & & & & & & & \\
\hline \multicolumn{23}{|l|}{ Pengelolaan kegiatan ujian } \\
\hline \multicolumn{23}{|l|}{\begin{tabular}{|l|l|} 
Pengelolaan kegiatan \\
Praktik Kerja Lapangan \\
Pengelolaan kegiatan
\end{tabular}} \\
\hline $\begin{array}{l}\text { Pengelolaan kegiatan } \\
\text { PPM }\end{array}$ & & & & & & & & & & & & & & & & & & & & & & \\
\hline \multicolumn{23}{|l|}{ Pengelolaan Beasiswa } \\
\hline \multicolumn{23}{|l|}{\begin{tabular}{|l}
$\begin{array}{l}\text { Pengelolaan administrasi } \\
\text { Surat }\end{array}$ \\
\end{tabular}} \\
\hline \multicolumn{23}{|l|}{ Pengelolaan UKM } \\
\hline 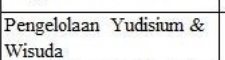 & & & & & & & & & & & & & & & & & & & & & & \\
\hline $\begin{array}{l}\text { Pengelolaan Trakskrip dan } \\
\text { Ljazzh }\end{array}$ & & & & & & & & & & & & & & & & & & & & & & \\
\hline
\end{tabular}

Figure 4. Data Entity/Business Function Matrix

2. Application Architecture

The various applications owned by the Triputra Persada Horizon Education Foundation are currently still separate. The database for each application is still not centralized. These applications are currently used to support academic activities at STIKes and STMIK. This is not in line with the ongoing business process because it has combined the business processes between STMIK and STIKes Kharisma Karawang into one integrated business process but has two different scientific fields. The list of applications currently available is as in Table 1.

Table 1. List of Applications at Triputra Persada Horizon Education Foundation

\begin{tabular}{|c|l|l|l|}
\hline No. & Nama Sistem & Akses & Database \\
\hline 1. & Official Website of STMIK & internet & independent \\
\hline 2. & SIAKAD STMIK & internet & independent \\
\hline 3. & Library Information system of STMIK & localhost & independent \\
\hline 4. & Questionnaire Information system of STMIK & localhost & independent \\
\hline 5. & Webite Official STIKes & internet & independent \\
\hline 6. & SIAKAD STIKes & internet & independent \\
\hline 7. & Library Information system of STIKes & internet & independent \\
\hline
\end{tabular}

From Table 1, it can be seen that the Triputra Persada Horizon Education Foundation has redundant applications and is not in accordance with the business processes described in the value chain analysis. In this case the author suggests to build a University Management Software with a module design as shown in Figure 5. 


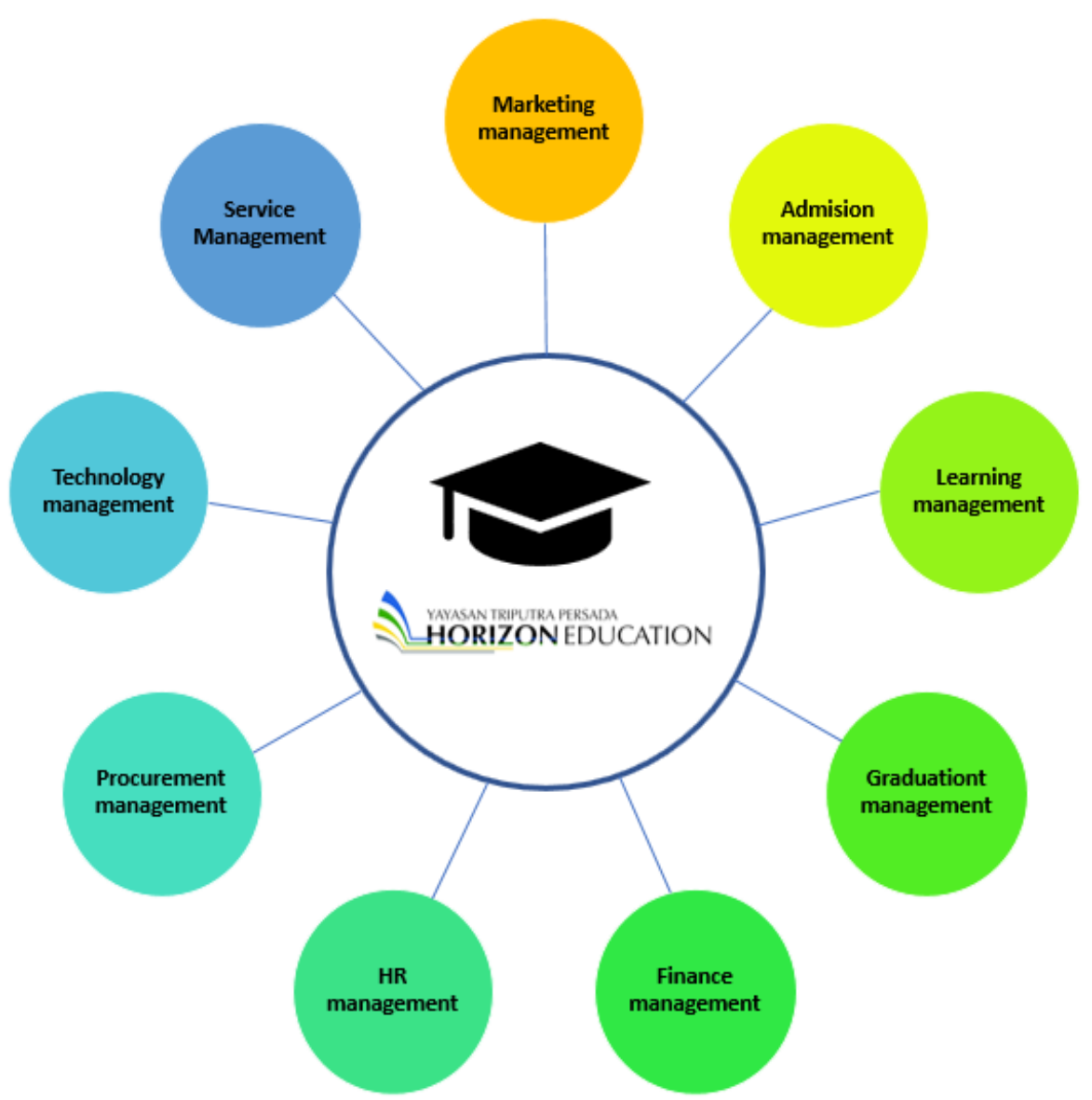

Figure 5. University Management Software Module Design

\section{E. Technology Architecture}

At this stage, a technology architecture that supports the vision is defined. Figure 6 shows the condition of the existing computer network architecture at the Triputra Persada Horizon Education Foundation, the current computer network architecture needs changes to support the proposed information system architecture. After the analysis, it is necessary to change to be as shown in Figure 7. With the fulfilment of business architecture, information system architecture, and technology architecture, a blue print can be produced which can later be used to develop the Triputra Persada Horizon Education Foundation.

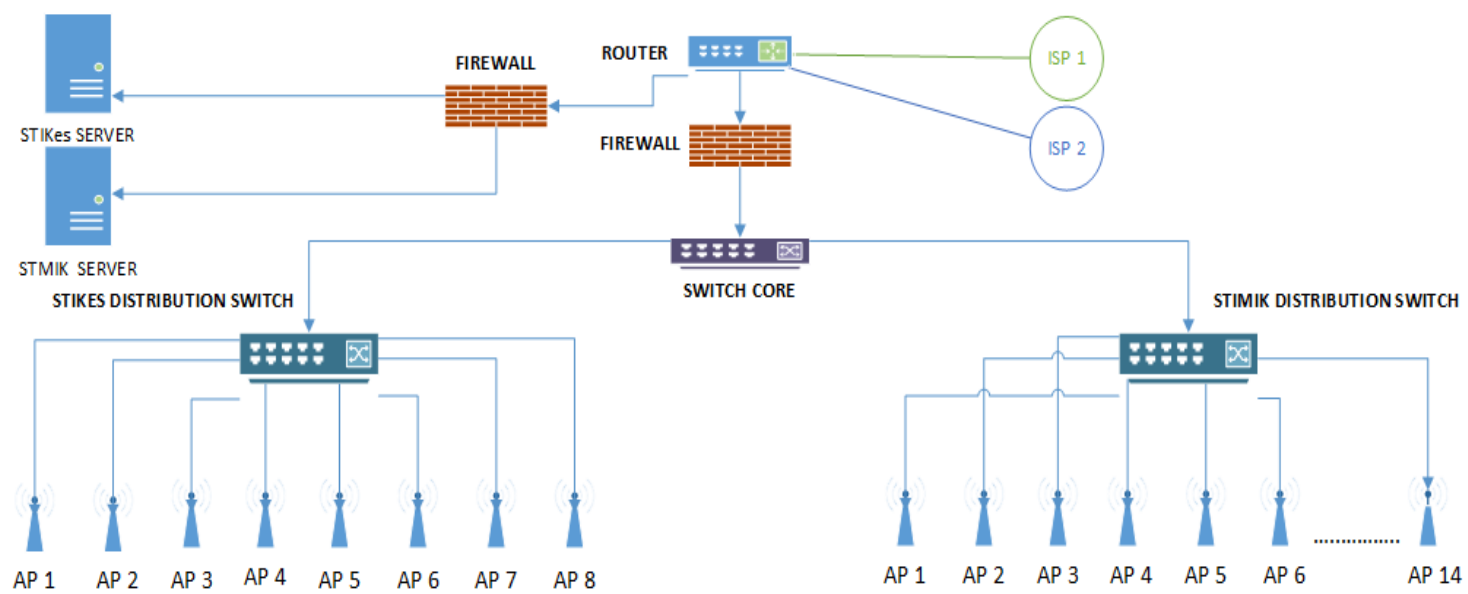

Figure 6. Networking Architecture at Triputra Persada Horizon Education Foundation 


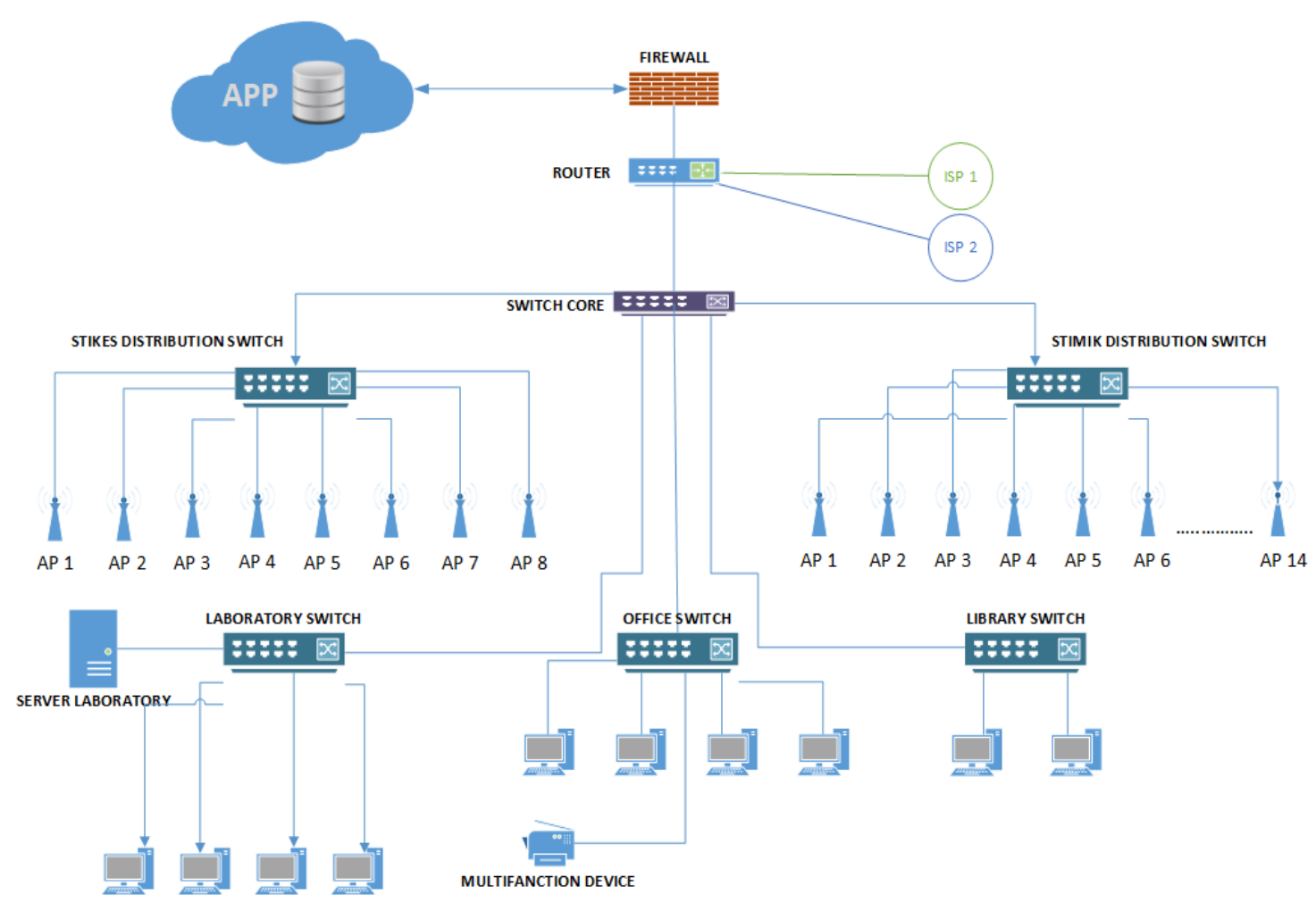

Figure 7. Proposed Network Architecture

\section{Conclusion}

Based on the results of the research described in the results and discussion guided by the stages of the research, it can be concluded that we produced recommendations for strategic and integrated information systems between departments that can support business processes within the organization. We produced recommendations on technology architecture that can support the proposed information system and other business processes. An enterprise architecture model needs to be produced that can be used as a reference to realize the organization's vision. In addition, it can be used as a guideline for determining policies in IT/IS Governance. Based on the results of this study, there are several suggestions put forward as follows we need to propose modules for the development of a more integrated system in order to facilitate the creation of the system. We need to propose system development method in making the system. Technology architecture includes the use of technology in detail specifications to make it easier to make recommendations in determining the required equipment.

\section{References}

[1] Mulyanto, A., "Pengertian Sistem Informasi dalam Sistem Informasi Konsep dan Aplikasi.“.Yogyakarta: ANDI, 2009.

[2] Nurfadillah, Y., dan Setiawan, R., "Pengembangan Aplikasi Pengendalian Tugas Akhir Berbasis Web Sisi Mahasiswa, Dosen, Dan Staff USI”, Jurnal STT-Garut, Vol. 13. No. 01, 2016.

[3] TOGAF® 9 Foundation Study Guide 4th Edition: Preparation for the TOGAF 9 Part 1 Examination. 2018

[4] Ambler. S.W., 2005. "The Enterprise Unified Process: Extending the Rational Unified Process".

[5] Kourdi, H. (2007). "Framework for Enterprise Architecture". IEEE.

[6] Yunis, R., Surendro, K. (2008). "Pemilihan Metodologi Pengembangan Enterprise Architecture untuk Indonesia". Prosiding SNIKA. Vol. 3, No.1, pp A53-A59.

[7] Mubarok A., Tjahjadi, D. (2019). "Pemodelan Arsitektur Enterprise Sistem Informasi Customer Relationship Management Menggunakan Enterprise Unified Process". ILKOM Jurnal Ilmiah Vol. 11, No.3,231-240,2019.

[8] Retnawati Lestari., (2018). "Perancangan Enterprise Architecture Menggunakan TOGAF di Universitas ABC". Jurnal IPTEK. Vol.22, 13-20, 2018

[9] Rusli, C.Y., Risqiati, Sulistyorini.P.(2018). "Penerapan Model the Open Group Architectural Framework (Togaf) Untuk Perancangan Arsitektur Enterprise (Studi Kasus Stmik Widya Pratama Pekalongan)", Prosiding Edusainstek UNIMUS, 2018

[10] Ully Novianti S., Tristiyanto . (2017). "Perencanaan Arsitektur Aplikasi Universitas Lampung Menggunakan Zachman Framework". Jurnal Komputasi. Vol 5 No. 1, 50-59, 2017 
[11] IBM., Business Systems Planning: “Information System Planning Guide”, New York, USA: International Business Machines Corporation, 1987.

[12] Hadiana, A., "Perencanaan dan Pengembangan Sistem Infromasi Terpadu". Megatama, Bandung, 2016.

[13] Pereira, C. M. dan SOUSA, P., "A Method to Define an Enterprise Architecture Using the Zachman Framework", Proceeding at the ACM Symposium on Applied Computing, 2004

[14] The Open Group. Open Group Standard TOGAF® Version 9.1, 2009.

[15] Porter, M, E., Competitive Advantage: Creating and Sustaining Superior Performance for Analyzing Industries and Competitor, 1985. 